\title{
Regional Consolidation of Party Support
}

The character of the territorial integration (see Chapter 4) explains much of the basic variation in Finnish political ecology. It created crucial preconditions for the national and class integration consolidated after the political mobilisation of 1905 .

\section{Regions as Loci of Party Systems}

Interpretations of regional variations in political mobilisation commonly start with mobilisation itself. They begin by looking at geographic voting patterns, for example, and then compare them with other distributions - the proportion of the rural proletariat, or the areas of small, medium, and large farms, and so forth. If the fit between the two maps is good, the latter structural variables serve to explain the distribution of the vote. ${ }^{1}$

In Finland, explanations given for the main regional variation in party support are based, naturally enough, on differences in the social structure of the agrarian population in various regions. It has been shown that the areas of greatest Social Democratic support were those with the largest proportion of crofters, industrial and agrarian workers, and people without permanent occupations, ${ }^{2}$ making up a zone running from the south-west to the north-east and extending into the far north. Similarly, the fact that the Agrarian Union (and before it the Young Finns) received greater support in the zone running from the south-east to the north-west, and also extending into the far north, than in the country as a whole has been explained by reference to the large number of medium-sized and small farms in this zone. And finally, the existence of Finnish party strongholds in the west has been explained by the prevalence of large landholdings in this area. ${ }^{3}$ As the Finnish historian Eino Jutikkala sums it up, 'In order to explain the geographical distribution of party support it is necessary to determine the largest common factor from which different attitudes [to fundamental political issues] may be derived. ${ }^{4}$

1 See 'Editorial Essay' in the first issue of Political Geography Quarterly $(1981,8)$.

2 Soikkanen 1961, pp. 368-89.

3 Von Bonsdorff 1954, pp. 54-5, 131-2, 175-8o; Salokangas 1975, pp. 175-8.

4 Jutikkala 1974, 143. 
The problem is that a similarity of causes is inferred from a similarity of final outcomes. Logically, however, this situation does not necessarily hold. The inference is unjustified if the same outcome can be derived from different starting points. This variability is exactly what the state-making approach to political mobilisation maintains. National political integration is closely linked to state-making, which amounts to the hypothesis that in the process of political integration locally defined conflicts are fused together on an emerging national level. 'Indeed', Charles Tilly has pointed out, 'the process of urbanization facilitates the reforming of persistent local rivalries along lines that have some significance throughout the society'. ${ }^{5}$

This approach suggests that one and the same party may have been supported in various regions for somewhat different reasons. In the mobilisation process different local issues took on a uniform national form. For example, in one area the vote was divided between the Social Democrats and the Finnish party, and in another between the Social Democrats and the Agrarian Union. The Social Democrats may have gained support in both areas, but their backing was basically linked to two different local conflicts. An approach that focuses on territorial integration makes one aware of the possible regional character of political mobilisation institutionalised in the party system. This does not imply that structural explanations of the type cited above should be abandoned, but if one is interested in the formative phase of a particular political ecology, it is desirable to look at the parties within the framework of the established regions rather than that of the state as a whole. The state-making perspective suggests a common framework for analysing both the consolidation of various regions and regional variations in political mobilisation.

Table 10 shows the combination of party support in the countryside in five regions. As stated above, these regions had different roles in the national division of labour, and this situation was reflected in differences in class structures. At the same time, the capitalist transformation increasingly generalised the industrial class conflict (see Chapter 4). Various regional conflicts were soon fused at the emerging national level - as indicated by the small number of nationally important parties - but they displayed their importance by forming regionally different combinations of party support. The initial regional differences in the strength of the various parties have persisted largely unchanged. It is to be noted, however, that in the 1920s, after the abortive revolution and the foundation in 1918 of the Communist party, support from the worker movement was split between the Social Democrats and the Communists. Also, the

5 Tilly 1964, p. 64. 
TABLE 10 Regional variations in political mobilisation in the Finnish countryside, 1907-1932

\begin{tabular}{|c|c|c|c|}
\hline Region & Political parties supported & $\begin{array}{l}\text { Role in abortive revolution } \\
\text { of } 1918\end{array}$ & $\begin{array}{l}\text { Role in Lapua move- } \\
\text { ment of } 193^{\circ-2}\end{array}$ \\
\hline South-western Finland & $\begin{array}{l}\text { Social Democrats and } \\
\text { Finnish party }\end{array}$ & Actively revolutionary & Active \\
\hline County of Viipuri & Agrarian Union & Passively anti-revolutionary & \\
\hline Ostrobothnia & $\begin{array}{l}\text { Finnish party and Agrarian } \\
\text { Union }\end{array}$ & Actively anti-revolutionary & Active \\
\hline Eastern Finland & $\begin{array}{l}\text { Social Democrats and } \\
\text { Agrarian Union }\end{array}$ & Passive & \\
\hline Northern Finland & $\begin{array}{l}\text { Agrarian Union and Social } \\
\text { Democrats }\end{array}$ & Passive & \\
\hline
\end{tabular}

Agrarian Union did not succeed in making itself into a national party - at the expense of the liberal Young Finnish party (the Progress party), especially in eastern and northern Finland - until the 1910s and 192os.

The areas where the Swedish party was strongest (omitted from Table 10) were contiguous with the boundaries of the Swedish-speaking regions on the western and southern coasts. The party even attracted the vote of Swedishspeaking workers. For this linguistic minority, then, the relevant conflict was determined not regionally, but rather relative to the Finnish-speaking majority. ${ }^{6}$

In the south-west both the industrial and the agrarian proletariat were numerous. Together with the crofters, they brought the Social Democrats 43 percent of the vote in 1907. More than anywhere else, the socialist challenge was here organised both in population centres and in the countryside, as indicated by the great number of rural worker associations. Barrington Moore's discussion of radical or rebellious solidarity among peasants seems applicable here. ${ }^{7}$ To create this solidarity, institutional arrangements must be such as to spread grievances throughout the peasant community and turn it into a solidarity group

6 See Allardt and Miemois 1982, pp. 266-7, 276-8.

7 Moore 1966, pp. 475-7. 
hostile to the overlord. This may happen if property arrangements require a minimum amount of property, usually land, in order to be a full member of the village. As Moore points out, the process of modernisation may considerably increase the number of those below this minimum, creating a radical potential. In the south-west, with the increase in the population this number did steadily grow, making the struggle for land more acute than elsewhere and presumably increasing the radical potential. Land prices rose not only as a result of the timber boom but also as a result of attempts by crofters and smallholders to buy land. ${ }^{8}$

Both crofters and landless labourers generally supported the Social Democrats in the elections. Despite their common hunger for land, however, no close alignment into a solidarity group was effected: after the first wave of mobilisation few crofters were active in the rural worker associations. ${ }^{9}$ This circumstance may be accounted for by the fact that the crofters were still able to maintain de facto control of the land they cultivated, whereas the landless were forced to compete for this asset. ${ }^{10}$

The Finnish party, that is, the Old Finns, gained 25 percent of the total vote in the south-west and soon developed into a distinctly conservative party, receiving its main support from independent peasant landowners, who, along with the clergy and the Ostrobothnian peasants, had earlier constituted the core for Fennomania. Indeed, the prosperous peasants of the south-west especially helped to delineate the agrarian and religious ideology of the late nineteenth century. When the modern capitalist class conflict emerged in this core region, not only in industry but also in agriculture, the conflict soon reproduced itself in the division between the socialist and the conservative parties.

The religious character of the Finnish party is understandable. It is not uncommon for the agrarian upper classes to defend their position in religious and other moral terms during large-scale political transformations accompanying the rise of capitalism. ${ }^{11}$ But here religion was characteristically not as revivalist as in most other regions. Whereas religion had traditionally been essential in the south-western countryside for the maintenance of hierarch-

$8 \quad$ Kivialho 1927, pp. 181-6.

9 This situation is striking for the agrarian commune of Huittinen, which is representative of crofter areas in the south-west (Alapuro, unfinished study [appeared in 1994: Risto Alapuro, Suomen synty paikallisena ilmiönä, Helsinki: Hanki ja Jää]). The crofters' meagre participation in the Social Democratic organisation for the tenant farmers is well known (Soikkanen 1975, pp. 114, 119, 152).

$10 \quad$ Cf. Soininen 1974, p. 398.

11 Moore 1966, pp. 490-3. 
ical relationships in peasant society, ${ }^{12}$ now, as class conflict became open, it acquired new importance in the form of 'church religiosity'. It became part of the new ideological equipment of the agrarian upper class.

\section{3}

\section{The County of Viipuri}

The strength of the Agrarian Union in the county of Viipuri seems to result from the fact that the peasants, as small producers and sellers of their labour power who worked in transportation and different seasonal jobs, were dependent on the market. ${ }^{13}$ The proximity of St. Petersburg remained important, but between 1867 and 1891 the domination of large areas by Russian nobles was eliminated as their lands were purchased by the Finnish state and allotted to the peasants. This process freed a large number of peasants from feudal relations.

The Agrarian Union was anti-capitalist and very hostile to bourgeois society, which was seen as dominated by urban elements. As the party's ideological founder expressed it, 'Towns have become fortresses for bourgeois society, from which the surrounding countryside is dominated'; large-scale industry and big business had endowed the towns with power and influence. The first party groupings emerged on a local basis in Ostrobothnia and the county of Viipuri immediately after the parliamentary reform and quickly gained a large share of the vote. ${ }^{14}$ The generalisation in Table 10 is less valid for the county's western areas than for its eastern areas, where the Agrarian Union gained 24 percent of the rural vote in 1907 and 54 percent in 1919. In the industrial centres of the western areas, the Social Democrats had several strongholds.

\section{4}

\section{Ostrobothnia}

Michael Hechter insists that relative isolation only rarely gives rise to a regionally distinctive culture that defines itself in active opposition to the culture of the core. He describes this exceptional case: 'Hypothesized conditions for the emergence of territorial counter-cultures include: the peripheral group must have a territory which facilitates intercollectivity communication; the peri-

\footnotetext{
12 Schmidt 1956b, pp. 25-6; Schmidt 1956a, pp. 86-7.

13 On the peasants' dependence on the market, see Engman 1983, pp. 149-58, 162.

14 Arter 1978, pp. 7-9, 48-58, 63-5. The leader cited is the Ostrobothnian Santeri Alkio (1919, p. 151).
} 
phery must be culturally and economically isolated from the national core, and oriented to some extra-national center; and the periphery must not engage in extensive trade, or other economic transactions, with the core. ${ }^{\prime}$

Each of these conditions was met in nineteenth-century Ostrobothnia. It was a territory where intercollective communication was relatively easy because of its geographically separate plain areas. It became increasingly isolated culturally because it remained outside the sudden transformation affecting other regions and therefore preserved its traditional communities. During the Swedish period it had been economically oriented toward Stockholm, and in the nineteenth century its main trading partner was still Sweden. Lastly, the network of railway lines developing from the south failed to provide Ostrobothnia with new trade connections before the 188 os.

Relative stagnation and isolation preserved the self-conscious spirit of enterprise characteristic of Ostrobothnian peasants. The tradition remained unbroken throughout the capitalist transformation, ${ }^{16}$ persisting in the rather homogeneous social structure. The stagnation seems to have been conducive to the preservation of the agrarian community as an effective frame for collective action, or to the rise of what Barrington Moore has called conservative solidarity among peasants, whereby those who have actual or potential grievances are tied into the prevailing social structure through a division of labour that provides a legitimate, though lowly, status for persons with little or no property. ${ }^{17}$ Something like conservative solidarity seems to have arisen in Ostrobothnia, where much of the growth in population was either channelled to areas outside the region via emigration or else tied to the prevailing structure by dividing the farm among the heirs or leasing a part of it to some of them at a nominal rent. Obtaining the wherewithal to buy a farm was often one of the most central motives for emigration, moreover, and a great many among the one-third who returned realised this wish. ${ }^{18}$

In Ostrobothnia, both strong parties - the Finnish party and the Agrarian Union - defended the agrarian way of life. In 1907 they gained two-thirds of the total vote in the Finnish-speaking areas. The Finnish party, which first predominated, received much support from the larger farms, whereas the Agrarian Union found backing among the smaller farms. ${ }^{19}$ Both displayed a very marked

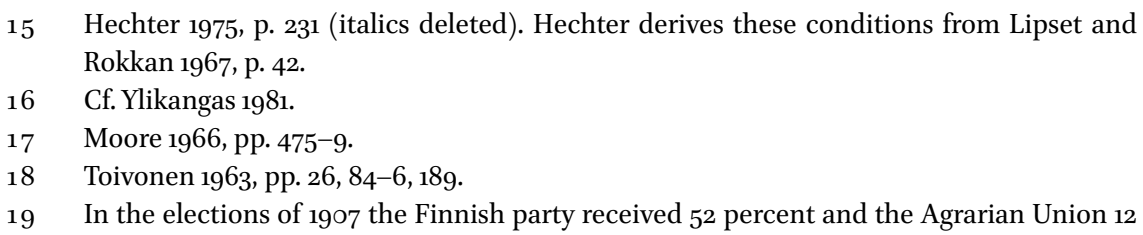


local colour, and the proudly provincial character of political mobilisation in this region was further accentuated by the strength of revivalism, which was stronger here than anywhere else at the end of the nineteenth century. Revivalism was connected with Finnish party support, and it was rooted in a viable traditional society. Typically, members of the clergy were central in both Ostrobothnian agrarian society and the revivalist movement. Youth associations, an advance guard of early mass organisation, were also more strongly represented here, particularly in the south, than anywhere else in the country.

The same point may be made in a slightly different fashion. In Ostrobothnia it was not essential to defend one's position and way of life in a situation of accentuated class conflict within the community, as was the case in the southwest. Rather, it was essential to defend the Ostrobothnian community and way of life inside Finland as a whole. Both the self-conscious provincial spirit and the moral indignation discernible in Ostrobothnian politics and revivalism may be attributed to the fact that the agrarian cultural pattern they represented was being irrevocably supplanted by the antagonisms and ways of life of capitalist society, which was advancing the integration of the rest of Finland.

\section{$5 \quad$ Eastern Finland}

In the first general elections the Social Democrats became the largest party in eastern Finland, gaining 49 and 44 percent of the vote in the counties of Kuopio and Mikkeli, respectively. Since then the support for the left has remained strong in this region.

In the county of Kuopio and in some neighbouring communes in the county of Vaasa, the liberal Young Finns became the second largest party, and together these two parties collected four-fifths of the vote. Elsewhere in the country this constellation was virtually unknown. In the late 191os and early 1920 s the province of Mikkeli definitely followed this pattern. Support for the Young Finns was not to be sustained to the same extent as that for the Social Democrats, however, and it was largely replaced by support for the Agrarian Union, which gained ground more slowly than in the county of Viipuri, Ostrobothnia, and the north. In the county of Kuopio the Young Finns lost ground to the Agrarian Union around 1920; in the county of Mikkeli this happened only in 1927, when the Agrarian Union was also advancing elsewhere.

percent of the total vote in the Finnish-speaking areas of Ostrobothnia 'proper'. On the social structure of the supporters of the respective parties, see Salokangas 1975. 
By and large, the Social Democrats, followed by the Young Finns and then by the Agrarian Union, were dominant in eastern Finland, and particularly in the county of Kuopio. During the formative period of the party system, this pattern was limited almost exclusively to this region. As in the south-west, support for the Social Democrats indicates the sharpness of class conflict. In the core region, class conflict became manifest especially in relations between agrarian groups, and support for the Social Democrats was accompanied by support for the conservatives. In eastern Finland the class conflict was affected by dependent industrialisation, making the region a periphery in the emerging territorial division of labour: Social Democrat support was accompanied, with a certain delay, by support for the Agrarian Union with its populist ideology. In both political tendencies a strong anti-capitalist feeling was evident; besides being socialist, anti-capitalism also had a peasantist base.

As in Ostrobothnia, the east experienced a revivalist movement, especially in the 183 os and 184 os, simultaneously with a distinct crisis in traditional slashand-burn cultivation. At the end of the century the movement was still alive but weaker than in Ostrobothnia, and the religious and political mobilisations were not as closely connected as in Ostrobothnia. Here isolated or scattered farmsteads predominated, and the agrarian society was undergoing fundamental change as the previous structure was undermined without being satisfactorily replaced. Hence, the eastern agrarian community seems to have had little potential for functioning as an effective frame for collective action. ${ }^{20}$

\section{$6 \quad$ Northern Finland}

The northern party division grew to resemble the eastern one in important respects, except that the Agrarian Union was stronger than the Social Democrats. As early as 1907 the Agrarian Union collected one-fourth of the vote, and in 1919 it gained an absolute majority. The Social Democrats' share in 1907 was 22 percent.

In this region there was, not surprisingly, distinct anti-state mobilisation, which during the general strike of 1905 became manifest in violence against and removal of state officials. ${ }^{21}$ Also, the parties had different ties with the social structure than elsewhere - which is one indication of the regional nature of party support. Here the crofters' vote was not as clearly linked to the Social

\footnotetext{
$20 \quad$ Cf. Moore 1966, p. 475.

21 Kyllönen 1975, pp. 147-8.
} 
Democrats as in other regions but was divided among the main parties. The Agrarian Union, especially, had a strong regional character, having in its early days a distinctively northern colour, owing mainly to its strength in northern Ostrobothnia and neighbouring areas in the north. ${ }^{22}$ An anti-state tendency has been identified also in the strong revivalist movement, Laestadionism, that obtained a strong foothold in the last decades of the nineteenth century both in northern Sweden and northern Finland. Politically, Laestadionism came to be linked mainly with the Agrarian Union. ${ }^{23}$ Finally, voter turnout remained the lowest here: in 1907 it ranged between 30 percent (in Lapland) and 63 percent, whereas in the country as a whole it was 71 percent.

Conclusions

In his study of the role of internal colonialism in British national development, Michael Hechter has distinguished two types of sectionalism: peripheral and functional. Peripheral sectionalism applies to situations in which a region's political distinctiveness results from cultural factors. In this case, the cause of political differences results from what is socially defined as the specific culture of the region. All political actors, whatever their class or occupational position, tend to unite behind the common elements of a regional culture, such as a distinctive language or religion. ${ }^{24}$ Functional sectionalism, in contrast, results from variations in the social-structural composition of a territory. In this case, class or occupational position determines the actor's political alignment, but certain strata - peasants, or industrial workers, for instance - are disproportionately located in particular regions. Hechter's evidence supports the view that the class-based party division gains strength following industrialisation in culturally homogeneous regions, regardless of whether these regions are advantaged or disadvantaged. ${ }^{25}$

In Finland it was functional sectionalism that became predominant following the capitalist transformation. Only the political distinctiveness of the Swedish-speaking regions can be attributed to cultural factors, and even here it is doubtful whether peripheral sectionalism applies. All this notwithstanding, it is nevertheless reasonable to view Finnish party formation in a regional perspective. The regional perspective seems reasonable, first, because, as indic-

\footnotetext{
22 Isohookana-Asunmaa 1980, pp. 51, 59, 227, and passim; Arter 1978, pp. 7-9.

23 Suolinna 1977; Kyllönen 1975, p. 161.

24 Hechter 1975, pp. 208-12.

25 Ibid., pp. 208-12, 331-40.
} 
ated above, it helps us see that the formation of an all-encompassing party structure was simply the way in which national integration was realised in the political sphere. The somewhat differing regional conflicts were reconstituted so that they could be dealt with in the framework of a single national system. Second, this perspective may enhance awareness of the parties' persistent regional peculiarities and the local conflicts that still exist. Both aspects, the advancement of national integration and the simultaneous preservation of certain regional traits, are discernible in the revivalist movements, in early mass organisations, and in party support.

One revivalist movement was active both in eastern Finland and in southern and central Ostrobothnia and was able to cross the cultural line traditionally separating these two regions. ${ }^{26}$ This was one of the first important signs of national integration among the peasants. ${ }^{27}$ Yet the movement's role in the two regions was different. Characteristically, in Ostrobothnia the leading figures were churchmen, who traditionally had a central role in the local community, whereas in eastern Finland the leaders were mainly laymen. In southern Ostrobothnia revivalism was linked to support for the Finnish party, in eastern Finland to support for the Agrarian Union. Similarly, Laestadionism had a distinctly regional character in the north, but it also expanded into central Ostrobothnia.

The early mass organisations spread throughout the country, but they had regional strongholds and different linkages in various regions. The tenacity of the underlying regional structure is perhaps most clearly discernible in the case of Ostrobothnia. There, all central mass organisations - the temperance movement, the youth associations, the farmers' societies - had a strong foothold. Local society organised itself into several mutually supporting organisations and into two main parties, each of which had a consciously provincial character. Both parties reflected peasant resentment against the upper gentry (although the gentry was more visible nationally than in Ostrobothnia). The provincial tone may even be seen in the consumer cooperatives. ${ }^{28}$ Furthermore, contacts between different organisations were not unknown: unlike youth and worker associations in the southwest, those in Ostrobothnia were able to cooperate long after $1905^{29}$

In the peripheral north the dominant party, the Agrarian Union, took a more anti-urban and anti-bureaucratic stand than elsewhere, and the early party

\footnotetext{
$26 \quad$ Ylikangas 1979, pp. 201-8.

27 Suolinna 1975, pp. 7-11.

28 Suonoja 1968, p. 94.

29 Ylikangas 1981, p. 231.
} 
programme was confined mainly to local problems. ${ }^{30}$ In its other stronghold, the county of Viipuri, the party was firmly rooted in the local structure as well. There, too, it arose in close connection with other mass organisations, notably the youth associations. And because of the county's smallholder basis, the party advocated the cause of small farmers more distinctly than in other regions, a situation that created some tension in the first years of the party's unification. ${ }^{31}$

In the south-west and in eastern Finland, the regional characteristics of political organisation were less obvious. In the south-western core class-based functional sectionalism was more evident than elsewhere. Conditions in the east illustrate how local conflicts can be moulded along nationally significant lines. There, the average farm was nearer the size of farms in western Finland than of the smallholdings in the county of Viipuri. ${ }^{32}$ Still, the eastern peasants were to vote mainly for the Agrarian Union. This may well be explained by the adverse effects of capitalist penetration in this region, but it is significant that the party's advance was slower there than in other Agrarian strongholds. The party was able to attract the support of the eastern farmers only after it had consolidated itself at the national level. One indication of the region's dependent position vis-à-vis the core of the country perhaps lies in the fact that only in the county of Kuopio can no correlation be found between support for the Social Democrats in 1907 and the proportion of households owning land. ${ }^{33}$ Landownership, in other words, did not necessarily lead to an anti-socialist stand.

$30 \quad$ Isohookana-Asunmaa 1980, pp. 51, 233.

31 Mylly 1975, p. 100; Arter 1978, pp. 37, 57-8.

32 Mylly 1975, p. 95. In contrast to the south-west, however, a distinct class of wealthy peasants did not exist in the east.

33 Soikkanen 1961, pp. 366, 368, 385 . 